12. Палагина И. В. Формирование рефлексивной культуры диалога при решении учащимися творческих задач/ И. В. Палагина, И.Н. Семенов // Человек в мире диалога : тезисы докладов и сообщений. - Ленинград : АН СССР, 1990. - С. 169-172. 13. Тайсина Э. А. Познавательный диалог и научная картина мира / Э. А. Тайсина // Человек в мире диалога : тезисы докладов и сообщений. - Л. : АН СССР, 1990.C. 210-212.

УДК 378.147

Галина Журба

\title{
ПСИХОЛОГО-ПЕДАГОГІЧНІ ОСНОВИ ПІДГОТОВКИ МАЙБУТНЬОГО ВИКЛАДАЧА СПЕЦТЕХНОЛОГІЙ
}

Журба Г. П. Психолого-педагогічні основи підготовки майбутнього викладача спецтехнологій.

У сучасних умовах ніяк не можна трактувати навчання тільки як формування у студентів певної системи знань, умінь та навичок. Формування мотиваційної сфери студентів здійснюється шляхом усвідомлення цільової установки, звертання уваги студентів не тільки на значущість певного навчального матеріалу для вивчення інших тем курсу, а й для подальшої професійної діяльності, добір цікавого, привабливого для студентів змісту, забезпечення професійної спрямованості цього змісту тощо.

Ключові слова: розумова діяльність студентів, методи навчання, міжпредметні зв'язки.

Журба Г. П. Психолого-педагогические основы подготовки будущего преподавателя спецтехнологий.

В современных условиях нельзя трактовать обучение только как формирование у студентов определенной системы знаний, умений и навыков. Формирование мотивационной сферы студентов осуществляется путем осознания целевой установки, обращения внимания студентов не только на значимость данного учебного материала для изучения других тем курса, но и для дальнейшей профессиональной деятельности, подбора интересного, привлекательного для студентов содержания, обеспечения профессиональной направленности этого содержания и т.д.

Ключевые слова: умственная деятельность студентов, методы обучения, межпредметные связи.

Zhurba G. P. Psycho-pedagogical bases of preparing of the future special technology teacher.

Under present conditions it can not be treated only as training students in forming a system of knowledge, skills and abilities. Forming the motivational sphere of students is done by understanding the target set, taking into account not only the students on the importance of the training material for the study of other topics of the course, but also for future professional activities, selection of interesting, attractive content for students, providing professional orientation of the content and more.

Key words: mental activity of students, teaching methods, interdisciplinary communication.

Найважливішим напрямком удосконалення процесу навчання $є$ врахування психологічних закономірностей пізнавальної діяльності студентів, активізація їхніх 
психічних процесів. Формування мотиваційної сфери студентів здійснюється через усвідомлення цільової установки, звертання уваги студентів не тільки на значущість певного навчального матеріалу для вивчення інших тем курсу, а й для подальшої професійної діяльності, добір цікавого, привабливого для студентів змісту, забезпечення професійної спрямованості цього змісту тощо.

Незаперечним $є$ той факт, що в сучасних умовах ніяк не можна трактувати навчання тільки як формування у студентів певної системи знань, умінь та навичок. Висувається завдання організувати навчання так, щоб воно максимально забезпечувало не тільки розумовий розвиток студентів, а й готовність до майбутньої професійної діяльності. Тому слід говорити не просто про навчання, а про навчання, яке розвиває, а також про діяльнісний підхід у навчанні.

Нині наявна значна кількість науково-теоретичних і науково-методичних праць, у яких аналізується сутність психолого-педагогічних основ підготовки майбутніх викладачів спецтехнологій (О. Овчарук, О. Пометун, Г. Терещук, А. Хуторський та ін.). Плідно досліджує проблему розумового розвитку учнів Н. Менчинська. Становить інтерес позиція Л. Занкова. Перелік найбільш загальних критеріїв розумового розвитку особистості подає Н. Левітов.

Проте, незважаючи на збільшення кількості наукових публікацій 3 проблем психолого-педагогічної підготовки студентів, необхідними $є$ розроблення способів реалізації взаємозв'язку освітніх, розвивальних та виховних функцій навчання.

Отже, дидактична проблема психолого-педагогічних особливостей підготовки майбутніх викладачів вимагає багатоаспектного підходу, синтезу й узагальнення накопичених ідей і практичних рішень.

Mema cmammi- схарактеризувати психолого-педагогічні основи підготовки майбутнього викладача спецтехнологій.

Ефективність навчання визначається не тільки змістом, а й способом діяльності щодо його засвоєння, або операційний компонент діяльності. Визначення операційного компонента навчальної діяльності і процес формування його у студентів становлять центральну психологічну проблему навчання людини. Засвоєння студентами системи дій, за допомогою яких здійснюється розв'язання навчальних завдань, утворює основний стрижень процесу учіння.

Навчальна діяльність має своїм змістом оволодіння узагальненими способами дій у сфері наукових понять, це діяльність студентів 3 опанування системи знань, навичок та умінь у процесі навчання [6]. Прямою метою і продуктом навчальної діяльності $\epsilon$ учіння. Учіння $є$ основою всебічного розвитку індивіда, формування особистості, підготовки студента до трудової діяльності. Результати учіння - знання, навички і уміння - $є$ елементами індивідуального досвіду людини. Засвоєння знань, навичок та умінь здійснюється через розв'язання студентом навчальних задач.

Одним з першочергових завдань удосконалення навчального процесу у вищий школі $\epsilon$ формування у студентів культури навчальної діяльності, виявами якої $\epsilon$ прагнення особистості до розвитку своїх інтелектуальних здібностей, удосконалення своєї діяльності, досягнення iї найвищого творчого рівня.

У психології і педагогіці вищої школи під активізацією навчальної діяльності студентів розуміють цілеспрямовану діяльність викладача, спрямовану на розроблення i використання такого змісту, форм, методів, прийомів та засобів навчання, які сприяють підвищенню інтересу, активності, творчої самостійності студента в засвоєнні знань, формуванні вмінь та навичок, застосуванні їх на практиці [5]. До поняття активізації навчальної діяльності дотичне поняття 
інтенсифікації навчання - відшукання можливостей передавання студентам обсягу інформації, який збільшується за незмінної тривалості навчання.

Проблеми активізації й інтенсифікації навчально-виховного процесу можуть розв'язуватись шляхом забезпечення адекватності зовнішніх форм і засобів навчання його внутрішньому змісту; інтенсифікації навчальної діяльності кожного окремого студента i, нарешті, інтенсифікації взаємодії викладача зі студентами і студентів між собою в навчальному процесі.

Питання інтенсифікації педагогічного процесу можуть розглядатись і більш детально стосовно окремих аспектів навчального процесу. Інтенсифікація може бути досягнута за рахунок удосконалення двох основних компонентів навчальновиховного процесу: змісту та методів навчання. Удосконалення змісту навчання щонайменше передбачає:

- раціональний добір навчального матеріалу із виокремленням основного, базового, і другорядного, додаткового;

- перерозподіл обсягу навчального матеріалу в часі з тенденцією максимальної концентрації нового в початковий період навчання;

- концентрацію аудиторних годин занять також на початковому етапі навчання;

- нерівномірне дозування навчального матеріалу для забезпечення багаторівневого відпрацювання нового матеріалу;

- забезпечення логічної наступності нового i опрацьованого навчального матеріалу та активне використання нового для більш глибокого засвоєння пройденого, виходячи із розуміння процесу пізнання як такого, що розвивається не лінійно, а за спіраллю;

- більш економне і раціональне використання кожної хвилини аудиторного часу.

Удосконалення другого компонента навчально-виховного процесу- методів навчання - забезпечується:

- широким використання колективних форм пізнавальної діяльності;

- формуванням у викладача відповідних навичок організації керування колективною навчальною діяльністю студентів;

- звертанням до різних видів проблемного навчання;

- удосконалення навичок професіонального педагогічного спілкування, яке сприяє мобілізації творчого мислення студентів;

- реалізацією індивідуального навчання в умовах групової взаємодії 3 використанням продуманого добору форм спілкування та навчальних завдань 3 урахуванням індивідуальних особливостей студентів, які входять до навчальних груп;

- рівномірним просуванням усіх студентів незалежно від початкового рівня їх знань та індивідуальних здібностей;

- широким використанням найновіших наукових даних у галузі психології формування особистості і соціальної психології колективу.

Задля активізації пізнавальних процесів викладач повинен подавати матеріал на високому науковому рівні i водночас доступно; прагнути використовувати можливості усної мови для керування увагою та сприйняттям (гучність, тембр, інтонація, паузи), звертати увагу студентів на найбільш значущі твердження, різноманітними способами створювати позитивний емоційний фон процесу навчання. Вагомим засобом активізації $\epsilon$ проблемне навчання, що грунтується на закономірностях творчого засвоєння знань i способів діяльності i передбачає специфічне поєднання прийомів та методів викладання й учіння, якому притаманні основні риси наукового пошуку. 
Критерієм значущості кожного заняття є рівень активності розумової діяльності студентів, який визначається такими компонентами, як: інтерес до учіння, ініціативність у навчальній роботі, самостійність і напруження розумових і фізичних сил задля досягнення пізнавальних цілей, які виникають у процесі навчання.

У стимулюванні пізнавальної активності велике значення має вміння викладача спонукати студентів до осмислення логіки й послідовності у викладенні певної теми, до виокремлення в ній головних і найбільш суттєвих положень. Значний ефект в активізації розумової діяльності студентів під час усного викладу матеріалу забезпечує прийом, який ставить їх перед необхідністю робити порівняння, зіставляти нові факти, приклади i положення з тим, що вивчалось раніше.

Процес навчання в педагогічному вищому навчальному закладі є одночасно дидактичним і психологічним. Найтісніше об'єднання засвоєння знань, формування професійних навичок і вмінь, наукового пошуку, розвитку вищих розумових якостей студентів, активізації їхньої пізнавальної діяльності реалізується в навчальному процесі через здійснення міжпредметних зв'язків.

Засвоєння студентами провідних світоглядних ідей навчальних дисциплін через визначення і реалізацію міжпредметних зв'язків повинно забезпечити єдність функцій освіти, розвитку i виховання у предметній системі навчання. Під впливом міжпредметних зв'язків пізнавальні уміння, які набуваються студентами, стають узагальненими, загальнопредметними і міжпредметними.

Міжпредметні зв'язки визначаються змістом математичних дисциплін. Г. Федорець уважає навчальну тему найбільш рухомою дидактичною ланкою, через усебічне розкриття провідних положень якої досягається розкриття провідних ідей навчальної дисципліни i взаємозв'язку наук. Отже, педагогічно доцільним є встановлення і подальша реалізація міжпредметних зв'язків на рівні навчальної теми. Саме тому провідні положення навчальної теми і провідні ідеї навчальної дисципліни постають інтегрувальним стрижнем, навколо якого вибудовується не тільки зміст, але й увесь навчальний процес.

Деякі дидактики [2] пропонують відокремлювати в робочих навчальних програмах теми, які не сприяють реалізації міжпредметних зв'язків, оскільки навчальні дисципліни $\epsilon$ основами наук, повнота та цілісність яких не можуть бути порушені.

Також не можна знехтувати значенням інформаційної культури педагогаформування знань, навичок та умінь, необхідних для використання комп'ютера як засобу своєї майбутньої професійної діяльності. Крім того, інформаційна культура всіх педагогів $є$ необхідною передумовою ефективної реалізації міжпредметних зв'язків між навчальними дисциплінами.

Специфіка підготовки студентів технологічних спеціальностей педагогічних вищих навчальних закладів зумовлена спрямованістю останньої на формування вмінь i навичок. Урахування цієї специфіки сприяє вдосконаленню структури курсів дисциплін, забезпеченню їхньої професійної спрямованості, цільової диференціації й раціоналізації.

Зміст професійної підготовки студентів складає певний обсяг системних наукових знань, практичних навичок i вмінь, а також світоглядних i моральноетичних ідей, якими має оволодіти студент у процесі навчання технічних дисциплін.

Здібності до учіння тісно пов'язані з розумовим розвитком особистості, але ці поняття не тотожні. Розумовий розвиток особистості відбувається не лише у процесі учіння, а й в інших видах людської діяльності. Здібність до учіння $є$ відносно стійкою індивідуальною особливістю людини і характеризує процес засвоєння знань легкістю та швидкістю здобуття знань, оволодінням прийомами розумової діяльності, 
уміннями організовувати знання в систему, сформованістю раціональних способів навчальної роботи.

\section{Література}

1. Власенко К. Формування умінь i навичок студентів вищих навчальних закладів у процесі евристичної діяльності / К. Власенко // Рідна школа. - 2005. № 4. - С. 55-60. 2. Гаврищак Г. Р. Компетентність та ключові компетенції викладача ВНЗ / Г. Р. Гаврищак // Матеріали регіонального науково-практичного семінару «Професійні компетенції та компетентності вчителя» (28-29 листопада 2006 р.) C. 31-32. 3. Герлянд Т. Сучасні аспекти формування професійної компетентності майбутніх викладачів спецдисциплін/ Тетяна Герлянд// Педагогіка і психологія професійної освіти : науково-методичний журнал. - 2010. - № 1-2. - С. 37-43. 4. Кадемія М. Й. Сучасні методи та інноваційні технології навчання / М. Ю. Кадемія // Професійно-технічна освіта. - 2004. - № 2. - С. 49-51. 5. Марігодов В. К. Системний підхід до підготовки проблемної лекції / В. К. Марігодов // Нові технології навчання: [наук.-метод. зб.] / М-во освіти і науки України, Ін-т інновац. технологій і змісту освіти. - К., 2007. - Вип. 46. - С. 10-16. 6. Погорслова Л. В. Деякі аспекти творчої діяльності в процесі навчання / Л. В. Погорєлова // Пробл. інж.-пед. освіти : [зб. наук. пр.] / Укр. інж.-пед. акад. - Х., 2007. - Вип. 18-19. - С. 125-132.

УДК 13.04

Лоліта Маліцька

\section{ВПЛИВ ЕТНОСТЕРЕОТИПІВ НА ФОРМУВАННЯ ОСОБИСТІСНОЇ СПРЯМОВАНОСТІ}

Маліцька Л. Б. Вплив етностереотипів на формування особистісної спрямованості.

Статтю присвячено актуальній проблемі етнічної ідентифікації в умовах соціально-політичної кризи. Розглядаються можливості соціалізації особистості, роль етностереотипів у цьому процесі, вплив етнічної ідентифікації на самореалізацію особистості в сучасному суспільстві.

Ключові слова: етнічна ідентифікація, етнічні стереотипи, соціалізація, самореалізація.

Малицкая Л. Б. Влияние этностереотипов на формирование личностной направленности.

Статья посвящена актуальной проблеме этнической идентификации в условиях социально-политического кризиса. Рассматриваются возможности социализации личности, роль етностереотипов в этом процесе, влияние этнической идентификации на самореализацию личности в современном обществе.

Ключевые слова: этническая идентификация, этнические стеретипы, социализация, самореализация.

Malitska L. B. Influence of ethnic stereotypes on forming personal orientation.

The article deals with actual problems of ethnic identification under conditions of the possibilities of personality's socialization, the role of ethnic identification in self-realization of personality at the modern society.

Key words: ethnic identification, ethnic stereotypes, socialization, self-realization. 